\title{
PENGEMBANGAN MODUL CETAK 1000 HARI PERTAMA KEHIDUPAN UNTUK PELATIHAN KADER BINA KELUARGA BALITA DI BKKBN
}

\author{
Yayat Nurhayati \\ email : yayat.nurhayati28@gmail.com \\ Badan Kependudukan dan Keluarga Berencana Nasional Provinsi Banten \\ Kawasan Pusat Pemerintahan Provinsi Banten, Jl. Syech Nawawi No. 2 Palima-Serang-Banten 42171

\begin{abstract}
Abstrak: Penelitian ini bertujuan untuk menghasilkan paket modul cetak 1000 Hari Pertama Kehidupan (HPK) untuk pelatihan Kader Bina Keluarga Balita (BKB) di BKKBN. Metode penelitian berbasiskan desain, dengan mengikuti langkah-langkah pengembangan dari Derek Rowntree. Penelitian ini menghasilkan empat buah modul dan satu buku panduan penggunaan bagi instruktur/widyaiswara. Partisipan dalam penelitian adalah kader BKB dan beberapa ahli yaitu ahli materi, ahli desain instruksional dan ahli bahasa. Penelitian dilakukan di BKKBN Pusat dan Perwakilan BKKBN Propinsi Banten. Untuk melihat kelayakan modul, peneliti melakukan validasi/telaah ahli, ujicoba face to face, dan ujicoba lapangan/ field trials. Hasil validasi dari ahli materi, ahli desain instruksional, dan ahli bahasa menyatakan bahwa keempat modul cetak 1000 Hari Pertama Kehidupan dinilai sangat baik. Sedangkan hasil ujicoba face to face dan field trials menunjukkan bahwa modul layak digunakan. Hasil t hitung diperoleh angka 17,09 dan $t$ tabel dengan taraf signifikansi, 0,05 adalah 1,72472, sehingga dapat disimpulkan bahwa modul ini efektif untuk meningkatkan hasil belajar peserta pelatihan.
\end{abstract}

Kata-kata kunci: pengembangan modul cetak, model Rowntree, 1000 HPK

\section{THE DEVELOPMENT OF THE FIRST 1000 DAYS OF LIFE PRINTED TRAINING MODULE FOR BINA KELUARGA BALITA CADRES IN BKKBN}

\begin{abstract}
The purpose of this research is to develop the First 1000 Day of Life printed training module for Bina Keluarga Balita (BKB) cadres in BKKBN. This modul package was develop to increase BKB Cadres' knowledge. About 1000 day of life. The backgroud of 1000 day of life research is to overcome the high number of stunting rate in Indonesia. Based on WHO data's, Indonesia take the fifth place of stunting rate in the world. This research applies Research and Development method (R\&D) using Rowntree model. The model consists of 1) planning, 2) preparing for writing and, 3) writing and re-writing. This research produced / generated four modules and a guide book for facilitators. Respondents in this study were BKB cadres and several experts namely material experts, instructional design experts and linguists. To see the feasibility of the module, researchers conducted validity / expert review, face to face tryout and field trial. The research showed that the First 1000 day of life module were feasible and effective to increase the learning outcomes of the training participants. The results of the t-test show that there are significant differences so that the First 1000 Day of Life print module is said to be effective in improving the learning outcomes of trainees.
\end{abstract}

Keywords: Development of Print Modules, Rowntree Model, The First 1000 Day of Life. 


\section{PENDAHULUAN}

Persoalan gizi buruk bukanlah masalah yang baru di dunia, walaupun sudah dilakukan berbagai upaya untuk mengatasinya, tetapi tetap saja masalah ini dianggap sebagai masalah utama dalam pembangunan kependudukan. Begitu juga di Indonesia, masalah gizi buruk ini masih menjadi satu persoalan utama dalam pembangunan sumber daya manusia. Kementerian Kesehatan (2015) menyatakan Hasil Pemantauan Status Gizi (PSG) tahun 2015 yang dilakukan oleh Kementerian Kesehatan di 34 Provinsi (496 Kabupaten/Kota), menunjukkan bahwa masalah gizi pada anak berusia di bawah lima tahun di Indonesia masih tinggi. Akibat masalah gizi yang akut tersebut menyebabkan $1 / 3$ anak Indonesia mengalami stunting. Bahkan Badan Kesehatan Dunia WHO mengatakan bahwa Indonesia berada di urutan ke-lima di dunia jumlah anak dengan kondisi stunting, dan menempati urutan ke-dua dari 9 negara di ASEAN dengan angka stunting tertinggi.

Menurut Dewi dalam Kompas.com (2017) "Stunting adalah masalah gizi kronis yang disebabkan oleh asupan gizi yang kurang dalam waktu yang lama. UNICEF juga mendefinisikan stunting sebagai persentase anak-anak usia 0 sampai 59 bulan, dengan tinggi di bawah 0 atau sampai minus 2 (stunting sedang dan berat) dan minus tiga (stunting kronis) diukur dari standar pertumbuhan anak keluaran WHO." Stunting dapat terjadi bila anak yang masih dalam kandungan hingga dilahirkan sudah mengalami kekurangan asupan gizi yang baik untuk pertumbuhan. Anak dengan kondisi stunting memiliki tinggi/panjang badan kurang dari ukuran ideal atau standar yang ada.

Kementerian Kesehatan (2015) menyatakan bahwa "untuk mengatasi dan menanggulangi tingginya angka stunting tersebut, maka pemerintah dalam hal ini Kementerian Kesehatan dan beberapa instansi terkait termasuk BKKBN, memfokuskan pada 1000 Hari Pertama Kehidupan (HPK), karena waktu terbaik untuk mencegah stunting adalah selama masa kehamilan dan dua tahun pertama kehidupan pada anak." Program 1000 Hari Pertama Kehidupan (HPK) membahas tentang bagaimana cara mempersiapkan kehamilan, merawat kehamilan, sampai pada mengurus dan mendidik anak dari usia 0 bulan sampai 2 tahun ( 270 hari selama kehamilan dan 730 hari dari lahir sampai balita berusia 2 tahun).

Terkait dengan permasalahan ini, BKKBN sebagai lembaga pemerintahan yang bergerak di bidang Kependudukan, Keluarga Berencana dan Pembangunan Keluarga (KKBPK), memiliki tugas penting untuk memperkenalkan dan menyampaikan program 1000 Hari Pertama Kehidupan (HPK) kepada masyarakat, khususnya kepada ibu hamil, ibu menyusui dan ibu yang memiliki anak usia 0-2 tahun melalui berbagai kegiatan penyuluhan di masyarakat. Kegiatan penyuluhan ini biasa dilakukan oleh para Petugas Lapangan Keluarga Berencana (PLKB) dan dibantu oleh para kader Keluarga Berencana (KB) yang merupakan ujung tombak pelaksanaan program KKBPK. Kader KB adalah seseorang atau sekelompok orang yang memiliki minat dan melaksanakan kegiatan-kegiatan yang berkaitan dengan program BKKBN.

Kader Bina Keluarga Balita (BKB) memiliki peranan yang penting dalam keberhasilan program 1000 Hari Pertama Kehidupan. Berdasarkan studi pendahuluan yang dilakukan peneliti, pengetahuan dan wawasan para kader BKB tentang 1000 Hari Pertama Kehidupan (HPK) masih kurang. Selama ini para kader mendapatkan informasi tentang 1000 Hari Pertama Kehidupan hanya dari iklan di media cetak dan elektronik, serta dari kegiatan pelatihan dan sosialisasi yang diselenggarakan BKKBN. Keterbatasan anggaran membuat tidak semua kader BKB dapat mengikuti kegiatan pelatihan atau sosialisasi, sehingga diperlukan sebuah bahan belajar mandiri yang dapat meningkatkan pengetahuan dan keterampilan para kader BKB tentang 1000 Hari Pertama Kehidupan.

Berdasarkan penjelasan di atas, artikel ini menjelaskan bagaimana mengembangkan Modul Cetak 1000 Hari Pertama Kehidupan (HPK) untuk Pelatihan Kader Bina Keluarga Balita (BKB) di BKKBN. Modul cetak yang telah dikembangkan berfungsi sebagai media pembelajaran 1000 Hari Pertama Kehidupan bagi Kader BKB. Modul yang akan dikembangkan dilengkapi dengan petunjuk penggunaan bagi instruktur pelatihan dan petunjuk bagi kader sebagai peserta pelatihan.

Menurut Heinich, Molenda, dan Russel (1990), "module is a free-standing, self-contained component of an instructional system." Definisi tersebut menjelaskan bahwa modul merupakan komponen mandiri dari sistem pembelajaran. Demikian juga Prawiradilaga dan Chaeruman (2018) menyebutkan "modul adalah materi ajar yang dipersiapkan untuk proses belajar mandiri." Sedangkan Ibrahim (2010) mendefinisikan "modul sebagai salah satu bahan belajar mandiri yang dirancang secara sistematis, terarah, dan terukur untuk mencapai tujuan pembelajaran."

Jadi, modul adalah bahan belajar mandiri yang dibuat dan disusun secara sistematis dan lengkap, 
yang dimanfaatkan oleh peserta didik untuk mencapai tujuan pembelajaran.

Modul sebagai bahan belajar mandiri memiliki ciri khas dan berbeda dengan bahan belajar lainnya. Suparman mengatakan (2014) penggunaan modul dalam pembelajaran memiliki tujuan sebagai berikut: (1) memperjelas dan mempermudah penyajian pesan agar tidak terlalu bersifat verbal; (2) mengatasi keterbatasan waktu baik pemelajar maupun pembelajar; (3) dapat digunakan secara tepat dan bervariasi, seperti meningkatkan motivasi dan gairah belajar pemelajar, mengembangkan kemampuan pemelajar dalam berinteraksi dengan lingkungan dan sumber belajar lainnya, memungkinkan pemelajar belajar mandiri sesuai kemampuan dan minatnya, memungkinkan pemelajar dapat mengukur atau mengevaluasi sendiri hasil belajarnya.

Adapun karakteristik modul menurut Heinich, Molenda, dan Russel (1990) yang dikutip Ibrahim (2010) adalah: 1) self instructional (belajar mandiri) yaitu melalui modul pemelajar mampu membelajarkan

Tabel 1

Perbedaan Buku Teks dengan Modul

\begin{tabular}{|c|c|}
\hline Buku Teks & Modul \\
\hline Mengasumsikan minat dari pembaca & Menimbulkan minat dari pembaca \\
\hline Ditulis terutama untuk digunakan pembelajar & Ditulis dan dirancang untuk digunakan pemelajar \\
\hline Belum tentu menjelaskan tujuan pembelajaran & Tujuan pembelajaran dijelaskan pada awal kegiatan belajar \\
\hline Disusun secara linear & Disusun berdasarkan pola belajar yang fleksibel \\
\hline Strukturnya berdasarkan logika bidang ilmu & $\begin{array}{l}\text { Strukturnya berdasarkan kebutuhan pemelajar dan } \\
\text { kompetensi akhir yang akan dicapai }\end{array}$ \\
\hline Belum tentu memberikan latihan & $\begin{array}{l}\text { Berfokus pada pemberian kesempatan bagi pemelajar } \\
\text { untuk berlatih }\end{array}$ \\
\hline Tidak mengantisipasi kesukaran belajar pemelajar & Mengakomodasi kesukaran belajar pemelajar \\
\hline Belum tentu memberikan rangkuman & Selalu memberikan rangkuman \\
\hline Gaya penulisan (bahasanya) naratif tetapi tidak komunikatif & $\begin{array}{l}\text { Gaya penulisannya (bahasanya) komunikatif dan semi } \\
\text { formal }\end{array}$ \\
\hline Sangat padat & Kepadatan berdasarkan kebutuhan pemelajar \\
\hline Dikemas untuk dijual secara umum & Dikemas untuk digunakan dalam proses pembelajaran \\
\hline $\begin{array}{l}\text { Tidak mempunyai mekanisme untuk mengumpulkan umpan } \\
\text { balik dari pemelajar }\end{array}$ & $\begin{array}{l}\text { Mempunyai mekanisme untuk mengumpulkan umpan balik } \\
\text { dari pemelajar }\end{array}$ \\
\hline $\begin{array}{l}\text { Tidak memberikan saran-saran cara mempelajari buku } \\
\text { tersebut }\end{array}$ & Terdapat penjelasan bagaimana cara mempelajari modul \\
\hline
\end{tabular}

Modul 1000 Hari Pertama Kehidupan merupakan modul yang membahas tentang bagaimana cara mempersiapkan kehamilan, merawat kehamilan, sampai cara merawat dan mendidik anak dari usia 0 bulan sampai 2 tahun (270 hari selama kehamilan dan 730 hari dari lahir sampai balita berusia 2 tahun), sehingga anak dapat terhindar dari bahaya stunting. Isi materi pada modul 1000 Hari Pertama Kehidupan (HPK) dikembangkan dan disusun sesuai dengan isi program 1000 Hari Pertama Kehidupan yang ada di BKKBN. diri sendiri, tidak tergantung pada pihak lain; 2) self contained (utuh), yaitu seluruh materi pembelajaran dari satu unit kompetensi atau sub kompetensi yang dipelajari terdapat di dalam satu modul secara utuh; 3) stand alone (berdiri sendiri), yaitu modul yang dikembangkan tidak tergantung pada media lain atau tidak harus digunakan bersama-sama dengan media lain; 4) adaptive (dapat disesuaikan), maksudnya modul harus memiliki daya adaptif yang tinggi terhadap perkembangan ilmu dan teknologi; 5) user friendly (akrab dengan pemakainya), modul hendaknya memberikan kemudahan bagi penggunanya, dan dapat diakses sesuai keinginan. Bahasa yang digunakan mudah dimengerti pemelajar dan dapat memotivasi untuk mempelajarinya.

Berdasarkan karakteristik modul tersebut sudah terlihat bahwa modul sangatlah berbeda dengan buku teks, sehingga Pannen dan Purwanto (2001) mengemukakan perbedaan modul dengan buku teks dari beberapa aspek sebagai berikut : 
memiliki tinggi badan pendek, tingkat asupan lemak rendah, jumlah anggota keluarga banyak dan memiliki sumber air minum yang tidak terlindungi beresiko mengalami stunting. Oleh karena itu disarankan agar keluarga membatasi jumlah anak sesuai dengan program Keluarga Berencana (KB).

Selanjutnya Torlesse, Cronin, Sebayang, dan Nandy (2018) dalam "Determinants of stunting in Indonesian children: evidence from a cross-sectional survey indicate a prominent role for the water, sanitation and hygiene sector in stunting reduction" mengidentifikasi faktor yang terkait dengan stunting di kalangan anak usia 0-23 bulan di Indonesia, sehingga dapat dirancang solusi kebijakan dan program yang tepat. Hasil penelitian ini menyatakan bahwa pengolahan air bersih, sanitasi, dan kebersihan lingkungan rumah berperan besar dalam meningkatkan angka stunting di Indonesia.

Hasil beberapa penelitian menunjukkan bahwa stunting merupakan masalah yang krusial yang mengancam balita di Indonesia dan hal tersebut banyak diakibatkan karena kurangnya pengetahuan para orangtua tentang 1000 Hari Pertama Kehidupan dan apa saja yang harus dilakukan pada periode tersebut. Selain itu dari beberapa penelitian pengembangan yang ada, modul terbukti dapat meningkatkan hasil belajar peserta didik, sehingga dalam penelitian ini peneliti ingin mengembangkan sebuah modul cetak tentang 1000 Hari Pertama Kehidupan bagi Kader Bina Keluarga Balita (BKB). Modul tersebut dapat digunakan sebagai referensi dan pedoman bagi para kader untuk memberikan penyuluhan kepada masyarakat tentang 1000 Hari Pertama Kehidupan.

Terkait dengan pengembangan media pembelajaran, beberapa penelitian pernah menggunakan model yang bervariasi. Martin, Hoskins, Brooks dan Bannett (2013), menghasilkan sebuah modul pembelajaran multimedia interaktif dengan mengadopsi model pengembangan ADDIE. Sanders, Faesi, dan Goodman (2013) dalam "A New Approach to Developing Interactive Software Modules Through Graduate Education", membahas sebuah pendekatan baru dalam pengembangan modul interaktif untuk pendidikan pascasarjana. Selain itu Himmah Rosyidah (2014) melakukan "Pengembangan Modul Kesehatan Reproduksi Remaja pada Siswa Kelas X SMAN 1 Menganti"

Model pengembangan Rowntree (1994) diadopsi sebagai acuan pengembangan modul cetak ini. Pada model Rowntree terdapat 3 (tiga) tahapan dalam mengembangkan modul cetak, yaitu tahap perencanaan, tahap persiapan untuk menulis, dan tahap menulis dan menyunting. Adapun bentuk gambar model Rowntree sebagai berikut

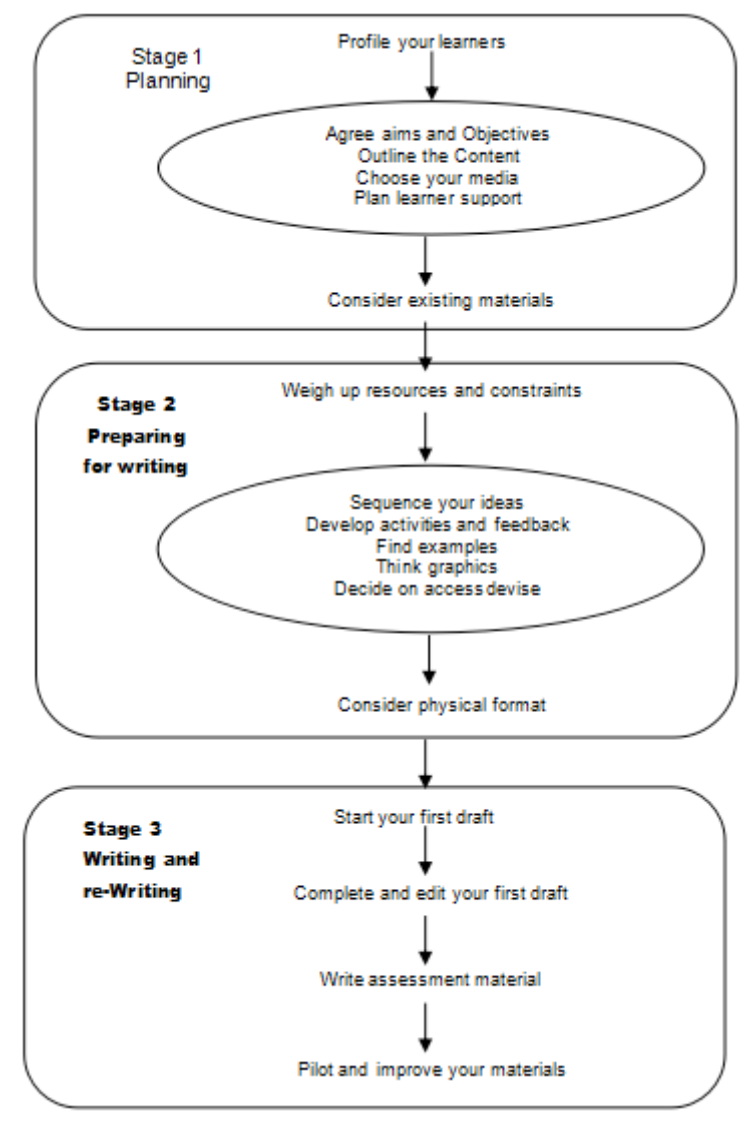

Gambar 1. Model Pengembangan Modul Cetak Yang Diadopsi (Rowntree, 1994) 


\section{METODE PENELITIAN}

Penelitian ini merupakan penelitian berbasiskan desain produk yang mengadopsi langkah-langkah dari model pengembangan dari Derek Rowntree (1994). Model ini dipilih karena tujuan desain produk adalah untuk mengembangkan paket modul cetak 1000 Hari Pertama Kehidupan bagi Kader Bina Keluarga Balita (BKB). Tahapan pengembangan modul terdiri dari: tahap perencanaan, persiapan penulisan, tahap penulisan dan penyuntingan.

BKKBN Pusat yang beralamat di Jalan Permata No.1 Halim Perdanakusuma, Kebon Pala, Jakarta
Timur, dan Perwakilan BKKBN Provinsi Banten yang beralamat di KP3B (Kawasan Pusat Pemerintahan Provinsi Banten) JI. Syech Nawawi Al-Bantani No.2, Palima-Serang, menjadi lokasi pengembangan modul. Sasaran pengguna modul 1000 Hari Pertama Kehidupan (HPK) adalah kader Bina Keluarga Balita (BKB), yang. memiliki minat dan melaksanakan kegiatan-kegiatan yang berkaitan dengan program BKKBN, khususnya yang berkaitan dengan kegiatan kelompok Bina Keluarga Balita (BKB).

\section{HASIL DAN PEMBAHASAN}

\section{Hasil}

Pengembangan ini dimulai dengan melakukan studi pendahuluan, dengan melakukan wawancara dengan pejabat terkait di Direktorat Balita dan Anak (DITBALNAK), PUSDIKLAT BKKBN, Kementerian Kesehatan serta beberapa kader Bina Keluarga Balita (BKB) di BKKBN. Hasil wawancara menyatakan bahwa pada saat itu, baik BKKBN maupun Kementerian Kesehatan belum memiliki bahan belajar khusus tentang 1000 Hari Pertama Kehidupan. Selama ini informasi mengenai program 1000 Hari Pertama Kehidupan hanya diperoleh kader melalui iklan di media cetak dan elektronik serta kegiatan pelatihan dan sosialisasi yang diselenggarakan BKKBN dan Kementerian Kesehatan. Dalam Diklat Teknis Menjadi Orangtua Hebat yang diselenggarakan BKKBN, bahan belajar 1000 Hari Pertama Kehidupan yang digunakan hanya sebatas handout dan tampilan presentasi dengan power point saja, sehingga para Kader KB yang tidak dapat mengikuti kegiatan sosialisasi dan pelatihan tersebut mengalami kekurangan informasi tentang program 1000 Hari Pertama Kehidupan, khususnya tentang hal-hal yang harus dilakukan orangtua pada 1000 Hari Pertama Kehidupan seorang anak, sehingga anak dapat terhindar dari stunting. Oleh karena itu dibutuhkan bahan belajar yang dapat digunakan oleh semua pengelola program KB khususnya para kader BKB. Bahan belajar yang dikembangkan diharapkan bukan hanya bahan belajar yang dapat digunakan ketika pelatihan, tetapi juga dapat digunakan secara mandiri oleh para kader di wilayah kerjanya masing-masing.

Berdasarkan masalah yang ditemukan pada penelitian pendahuluan, maka diperlukan pengembangan dan rancangan bahan belajar berupa modul cetak tentang 1000 Hari Pertama Kehidupan, yang berisi tentang pengetahuan serta hal-hal yang harus dilakukan pada 1000 Hari Pertama Kehidupan. Mulai dari cara menjaga kesehatan anak, memberikan asupan gizi yang sehat dan seimbang, hingga cara memberikan stimulus agar pertumbuhan dan perkembangan anak menjadi lebih optimal sehingga dapat terhindar dari bahaya stunting.

Modul cetak 1000 Hari Pertama Kehidupan yang dikembangkan terdiri empat buah modul dan satu buku petunjuk penggunaan modul. Kelima set buku dan modul ini kemudian dikemas dan dimasukkan ke dalam kotak yang diberi cover dan judul "Modul 1000 Hari Pertama Kehidupan bagi Kader Bina Keluarga Balita (BKB). Tujuannya agar menjadi satu kesatuan belajar yang utuh

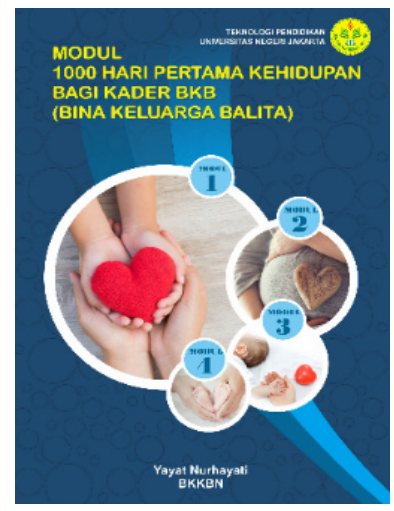

Gambar 2. Cover Kemasan Paket Modul dan Buku Petunjuk

Setiap modul terbagi menjadi beberapa kegiatan belajar. Dalam setiap kegiatan belajar terdapat tujuan pembelajaran, uraian materi, latihan, rangkuman, tes formatif, umpan balik (feed back), daftar pustaka, glosarium, dan pada akhir modul dilengkapi dengan 
kunci jawaban.

Paket modul 1000 Hari Pertama Kehidupan dilengkapi dengan buku petunjuk penggunaan modul yang berisikan latar belakang penulisan modul, tujuan pembelajaran, peta kompetensi, peta konsep isi modul, petunjuk penggunaan modul bagi instruktur/ pelatih, evaluasi modul, tes sumatif dan kunci jawaban tes sumatif.

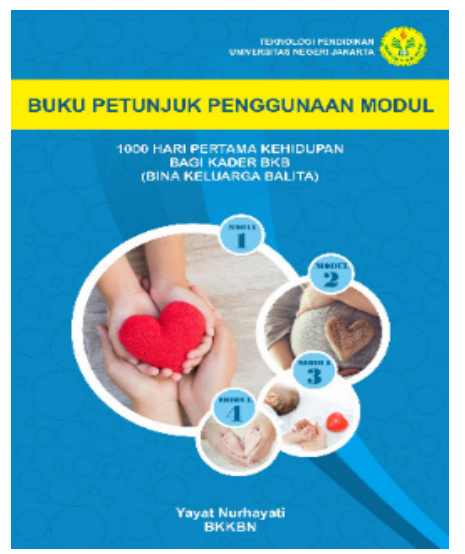

Gambar 3. Cover Buku Petunjuk Penggunaan Modul

Pertimbangan adanya pengetahuan yang perlu dikuasai oleh pengguna, maka periode 1000 Hari Pertama Kehidupan ini dibagi menjadi empat fase kegiatan utama. Keempat materi modul berisi tentang pengetahuan dan hal-hal yang harus dilakukan orangtua pada periode 1000 Hari Pertama Kehidupan, sehingga anak dapat terhindar dari stunting.

Rincian isi materi dalam setiap modul dipaparkan pada bagian berikut ini. Modul 1 Persiapan Kehamilan, terdiri dari 3 kegiatan belajar yaitu: (1) persiapan penting kehamilan; (2) nutrisi persiapan kehamilan; (3) persiapan menjadi orangtua, termasuk peran suami.
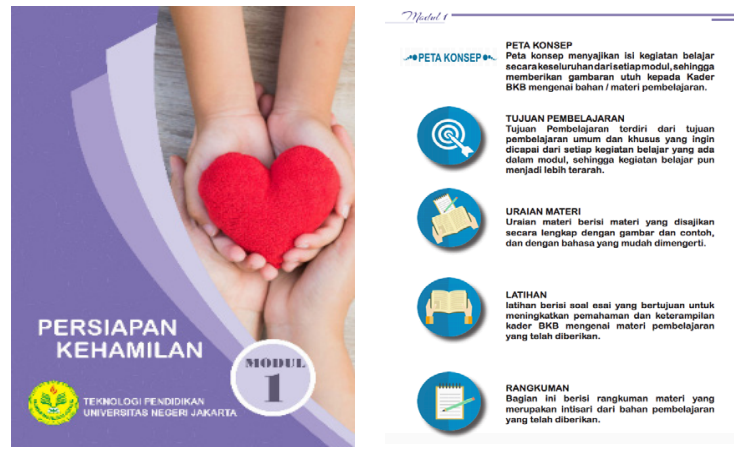

Gambar 4. Cover dan Bagian Petunjuk Penggunaan Modul

Modul 2 Masa Kehamilan, terdiri dari 3 kegiatan belajar yaitu: (1) perawatan kesehatan pada ibu hamil; (2) nutrisi penting bagi ibu hamil; (3) peranan suami pada masa kehamilan.
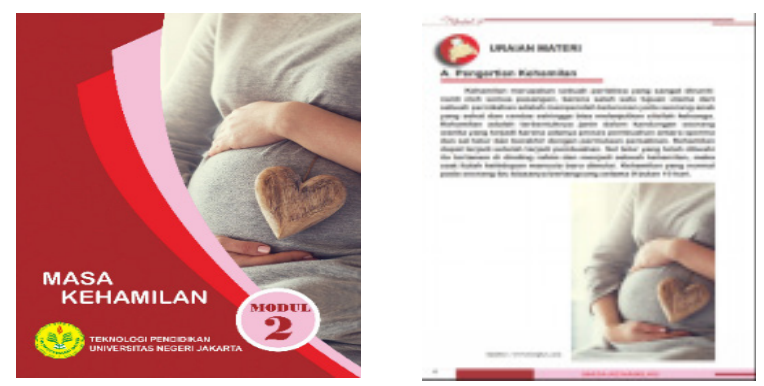

Gambar 5. Cover dan Bagian Uraian Materi Modul 2

Modul 3 Masa Persalinan, Nifas dan Menyusui, terdiri dari 3 kegiatan belajar yaitu: (1) Persalinan dan Masa Nifas; (2) pentingnya ASI Ekslusif; (3) Keluarga Berencana.
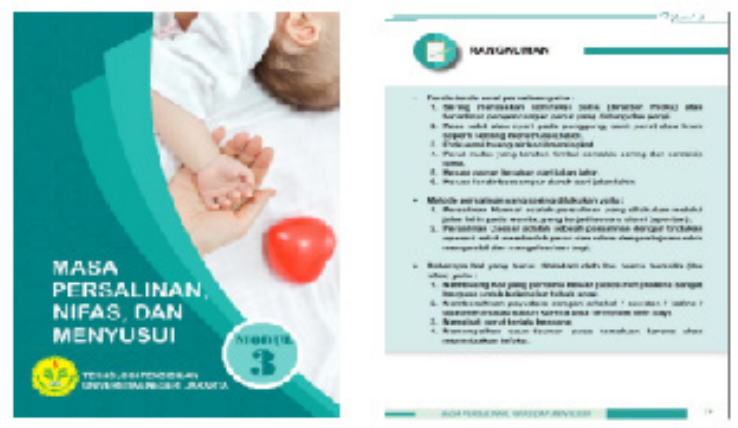

Gambar 6. Cover dan Bagian Rangkuman pada Modul 3

Modul 4 Masa Bayi-Balita (0-24 bulan), terdiri dari 4 kegiatan belajar yaitu: (1) perawatan kesehatan pada bayi-balita (usia 0-24 bulan); (2) kebutuhan gizi bayi-balita (usia 0-24 bulan); (3) peranan orangtua dalam pengasuhan anak; (4) mendorong tumbuh kembang anak.
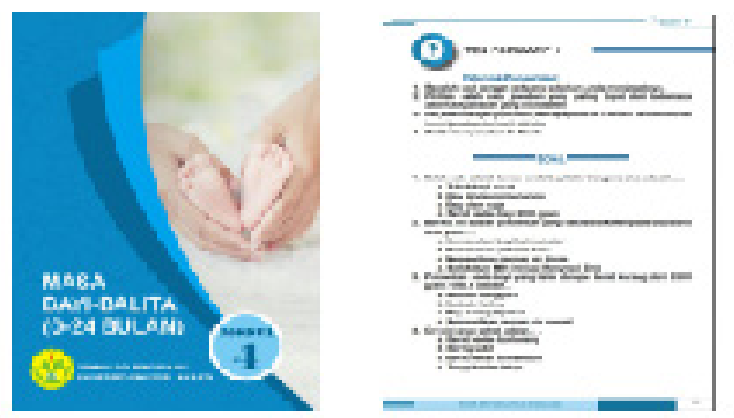

Gambar 7. Cover dan Bagian Tes Formatif pada Modul 4

Setelah dikembangkan draft modul 1, kemudian modul ditelaah dan divalidasi oleh ahli materi Khaeri Marifah, S.Psi, M.Psi, ahli desain instruksional Dr. Robinson Situmorang, M.Pd dan ahli bahasa Dr. Syamsi Setiadi, M.Pd menggunakan instrumen berupa kuesioner dengan skala Likert yang dimodifikasi. 
Instrumen dikembangkan berdasarkan kajian teoretik dan langkah-langkah penilaian menurut Rowntree. Peneliti juga membuat rentang dan skala nilai sebagai dasar penilaian dan pengambilan keputusan terhadap modul 1000 Hari Pertama Kehidupan, yaitu sebagai berikut: (1) nilai 3,26 -4,00 berarti sangat baik; (2) nilai 2,51 - 3,25 berarti baik; (3) nilai 1,76-2,50 berarti cukup; (4) nilai 1,00 - 1,75 berarti kurang baik.

Berikut ini adalah hasil telaah/validasi para ahli terhadap modul draft 1: telaah ahli materi (Subject matter expert) yang memvalidasi modul 1000 Hari Pertama Kehidupan bagi Kader BKB adalah Khaeri Marifah, S.Psi, M.Psi.T sebagai Widyaiswara BKKBN. Berikut ini adalah rekapitulasi hasil telaah ahli materi terhadap modul 1000 Hari Pertama Kehidupan:

Tabel 2

\section{Rekapitulasi Hasil Uji Ahli Materi}

\begin{tabular}{lc}
\hline \multicolumn{1}{c}{ Komponen } & \multicolumn{2}{c}{ Rata-rata } \\
Penilaian
\end{tabular}

Berdasarkan hasil telaah ahli materi terhadap modul 1000 Hari Pertama Kehidupan diperoleh skor rata-rata 3,53. Hasil tersebut menyatakan bahwa modul cetak 1000 Hari Pertama Kehidupan yang dikembangkan dari segi materi yang meliputi kelayakan isi materi, dan kelayakan penyajian sangat baik. Hal ini dapat dilihat pada gambar grafik hasil uji coba ahli materi sebagai berikut:

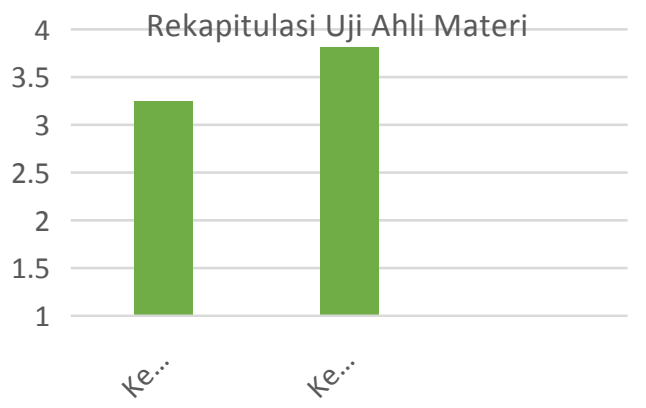

Gambar 3. Grafik Rekapitulasi Uji Akhir Materi

Telaah Ahli Desain Instruksional (Instructional Design Expert). Ahli desain instruksional yang menilai dan memvalidasi modul 1000 Hari Pertama Kehidupan adalah Dr. Robinson Situmorang, M.Pd, sebagai dosen di bidang Teknologi Pendidikan Universitas Negeri Jakarta. Berikut ini adalah rekapitulasi hasil telaah ahli desain instruksional terhadap modul 1000 Hari Pertama Kehidupan:

Tabel 3

Rekapitulasi Hasil Uji Ahli Desain Instruksional

\begin{tabular}{llc}
\hline \multicolumn{1}{c}{ Komponen } & \multicolumn{2}{c}{$\begin{array}{c}\text { Rata-rata } \\
\text { Penilaian }\end{array}$} \\
\hline A.Kesesuaian Tujuan Instruksional & \multicolumn{2}{c}{$\mathbf{3 , 2 4}$} \\
$\begin{array}{l}\text { 1.Perumusan Tujuan Instruksional } \\
\text { 2.Kesesuaian Strategi Instruksional }\end{array}$ & 3,38 & \\
B.Kelayakan Isi Modul & \multicolumn{2}{c}{$\mathbf{3 , 4 7}$} \\
1.Kesesuaian materi dengan TIU dan TIK & 4,00 \\
2.Keruntutan materi & 3,75 \\
3.Pendukung materi pembelajaran & 3,11 & \\
4.Metode dan evaluasi & 3,00 \\
C.Kelayakan Kegrafikaan & \multicolumn{2}{c}{$\mathbf{3 , 6 2}$} \\
1.Ukuran Modul & 3,50 \\
2.Desain Sampul Modul (Cover) & \multicolumn{2}{c}{4,00} \\
3.Desain Isi Modul & \multicolumn{2}{c}{3,37} \\
\hline \multicolumn{2}{c}{ Rata-rata } & (Sangat Baik) \\
\hline
\end{tabular}

Berdasarkan hasil telaah ahli desain instruksional terhadap modul 1000 Hari Pertama Kehidupan diperoleh rata-rata skor 3,44 . Hasil ini menyatakan bahwa modul cetak 1000 Hari Pertama Kehidupan yang dikembangkan dari segi desain instruksional meliputi kesesuaian tujuan instruksional, kelayakan isi modul dan kelayakan kegrafikaan sudah sangat baik. Hal ini dapat dilihat pada gambar grafik hasil telaah/ uji coba ahli desain instruksional. 


\section{Rekapitulasi Uji Ahli Desain Instruksional}

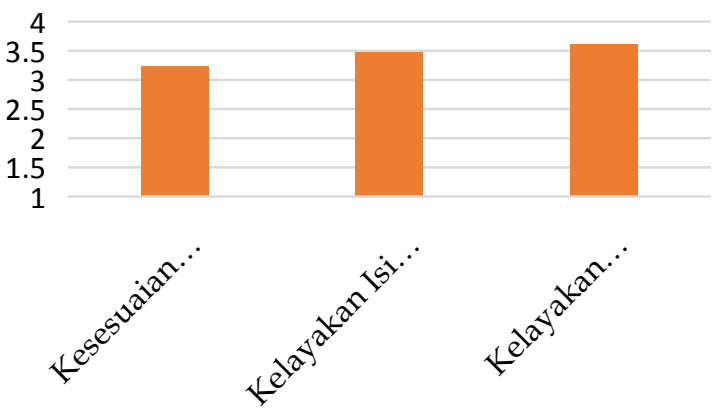

Gambar 4. Grafik Rekapitulasi Uji Ahli Desain Instruksional

Telaah Ahli Bahasa (Linguistic Expert). Ahli bahasa yang memvalidasi modul cetak 1000 Hari Pertama Kehidupan adalah Dr. Syamsi Setiadi, M.Pd., dosen di Fakultas Bahasa dan Sastra Universitas Negeri Jakarta. Berikut ini adalah rekapitulasi hasil telaah ahli bahasa terhadap modul 1000 Hari Pertama Kehidupan:

Tabel 4

Rekapitulasi Hasil Uji Ahli Bahasa

\begin{tabular}{lc}
\hline \multicolumn{1}{c}{ Komponen } & Rata-rata Penilaian \\
\hline A.Penilaian Bahasa & \\
1.Kesesuaian kemampuan & 4,00 \\
berbahasa peserta didik & \\
2.Ketepatan kaidah Bahasa & 3,60 \\
3.Pengunaan Gaya Bahasa & 3,86 \\
\hline \multicolumn{1}{c}{ Rata-rata } & 3,82 \\
& (Sangat Baik) \\
\hline
\end{tabular}

Berdasarkan hasil telaah ahli bahasa yang dilakukan terhadap modul 1000 Hari Pertama Kehidupan diperoleh skor rata-rata 3,82. Hasil tersebut menyatakan bahwa modul cetak 1000 Hari Pertama Kehidupan yang dikembangkan dari segi penggunaan bahasa sudah sangat baik. Hal ini dapat dilihat pada gambar grafik hasil uji coba ahli bahasa:

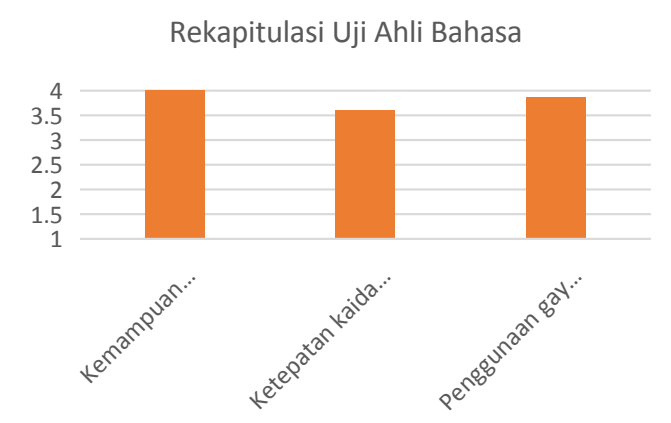

Gambar 5. Grafik Rekapitulasi Uji Ahli Bahasa
Berdasarkan hasil uji/telaah dari 3 pakar, maka diperoleh beberapa masukan dan saran terhadap modul 1000 Hari Pertama Kehidupan. Kemudian modul direvisi/diperbaiki berdasarkan saran dan masukan tersebut. Selanjutnya modul draft 2 , diujicoba face to face tryouts kepada pengguna modul yaitu Kader BKB. Adapun hasil penilaiannya adalah sebagai berikut :

Tabel 5

Rekapitulasi Hasil Ujicoba face to face

\begin{tabular}{|c|c|c|c|}
\hline \multirow{2}{*}{ Komponen } & \multicolumn{3}{|c|}{ Nilai Rata-rata } \\
\hline & Tinggi & Sedang & Rendah \\
\hline A.Pembelajaran & 3,33 & 3,44 & 3,44 \\
\hline $\begin{array}{l}\text { B.Fungsi dan } \\
\text { ukuran modul }\end{array}$ & 3,00 & 3,67 & 3,33 \\
\hline $\begin{array}{l}\text { C.Bahasa dan } \\
\text { struktur kalimat }\end{array}$ & 3,83 & 3,50 & 3,50 \\
\hline D.Tata Letak/ & 3,60 & 3,40 & 3,20 \\
\hline \multicolumn{4}{|l|}{ Layout } \\
\hline E.Tipografi & 3,50 & 3,50 & 3,50 \\
\hline F.llustrasi & 3,83 & 3,67 & 3,17 \\
\hline G.Warna & 4,00 & 3,33 & 3,67 \\
\hline \multirow[t]{2}{*}{ Rata-rata } & 3,59 & 3,50 & 3,40 \\
\hline & $\begin{array}{c}\text { Sangat } \\
\text { Baik }\end{array}$ & Sangat Baik & $\begin{array}{c}\text { Sangat } \\
\text { Baik }\end{array}$ \\
\hline Rata-Rata & & 3,50 & \\
\hline Keseluruhan & & (Sangat Baik) & \\
\hline
\end{tabular}

Berdasarkan hasil ujicoba face to face yang dilakukan terhadap tiga orang kader BKB diperoleh skor rata-rata keseluruhan yaitu 3,50. Hasil tersebut dapat disimpulkan bahwa modul cetak 1000 Hari Pertama Kehidupan untuk Pelatihan Kader Bina Keluarga Balita (BKB) di BKKBN, dari sisi desain pembelajaran, fungsi dan ukuran modul, bahasa dan struktur kalimat, tata letak/ layout, tipografi, ilustrasi, dan warna adalah sangat baik. Lebih jelasnya dapat dilihat pada grafik berikut ini:

\section{Rekapitulasi Hasil Ujicoba Face To Face}

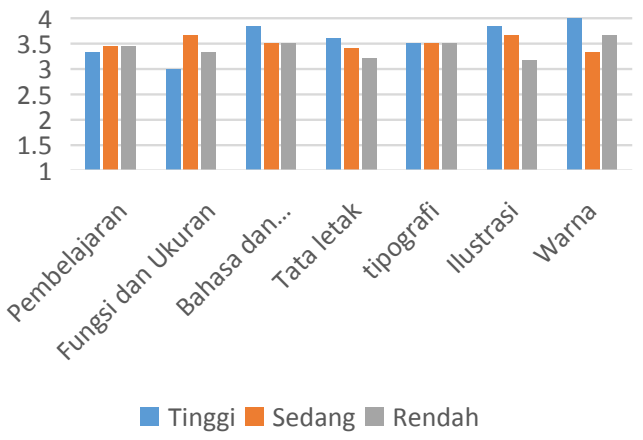

Gambar 6. Grafik Rekapitulasi Hasil Ujicoba Face To Face 
Berdasarkan hasil face to face tryouts kemudian modul diperbaiki sesuai saran, selanjutnya modul 1000 Hari Pertama Kehidupan diujicoba lapangan (field trial). Ujicoba lapangan melibatkan 20 orang peserta pelatihan. Pada ujicoba lapangan (field trial) ada dua kegiatan yang dilakukan yaitu : 1) Uji kelayakan modul, 2) Uji efektivitas modul. Uji kelayakan dilakukan dengan cara meminta kader BKB untuk menilai modul 1000 Hari Pertama Kehidupan dengan kuesioner. Berdasarkan hasil ujicoba field trials diperoleh hasil rekapitulasi penilaian kader BKB terhadap modul 1000 Hari Pertama Kehidupan sebagai berikut :

Tabel 6

Rekapitulasi Hasil ujicoba Field Trials

\begin{tabular}{|c|c|}
\hline Komponen & Nilai Rata-Rata \\
\hline A.Pembelajaran & 3,56 \\
\hline B.Fungsi dan ukuran modul & 3,58 \\
\hline C.Bahasa dan struktur kalimat & 3,67 \\
\hline D.Tata Letak/ Layout & 3,53 \\
\hline E.Tipografi & 3,68 \\
\hline F.llustrasi & 3,68 \\
\hline G.Warna & 3,76 \\
\hline Rata-Rata Keseluruhan & 3,64 \\
\hline Kesimpulan & Sangat Baik \\
\hline
\end{tabular}

Dari hasil tersebut diperoleh skor rata-rata keseluruhan 3,64. Hasil ini menyatakan bahwa modul cetak 1000 Hari Pertama Kehidupan bagi Kader Bina Keluarga Balita (BKB) di BKKBN dari segi pembelajaran, fungsi dan ukuran modul, bahasa dan struktur kalimat, tata letak / layout, tipografi, ilustrasi dan warna sudah sangat baik, ini berarti bahwa modul sangat layak digunakan. Hal tersebut dapat dilihat pada grafik berikut ini :

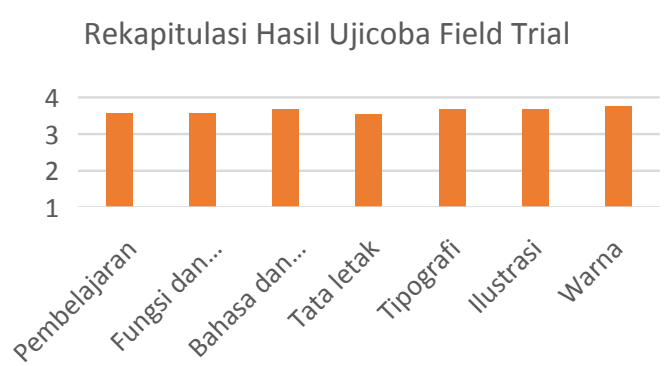

Gambar 7. Grafik Rekapitulasi Ujicoba lapangan (Field Trial)

Selanjutnya uji efektivitas modul dilakukan dengan memberikan pre-test dan post-test kepada Kader BKB. Berdasarkan hasil pre-test dan post-test, diperoleh hasil rekapitulasi pre-test dan post-test sebagai berikut:
Tabel 7

Rekapitulasi skor rata-rata pre-test dan post-test

\begin{tabular}{lc}
\hline \multicolumn{1}{c}{ Tahap } & Nilai Rata-Rata \\
\hline Pre-Test & 54,60 \\
Post-Test & 85,20 \\
Peningkatan & $\mathbf{3 0 , 6 0}$ \\
\hline Persentase & $\mathbf{5 6 \%}$ \\
peningkatan & \\
\hline
\end{tabular}

Berdasarkan tabel 7 di atas, diperoleh skor ratarata pre-test sebesar 54,60 dan skor rata-rata post-test sebesar 85,20. Berdasarkan skor tersebut dapat dilihat bahwa terjadi peningkatan sebesar 30,60 antara skor pre-test dan skor post-test, jika diprosentasekan terjadi peningkatan sebesar $56 \%$. Peningkatan tersebut menyatakan bahwa modul yang dikembangkan dapat meningkatkan hasil belajar peserta pelatihan. Peningkatan tersebut dapat dilihat lebih jelas pada gambar grafik di bawah ini:

\section{Perbedaan skor rata-rata pre-test dan post-test}

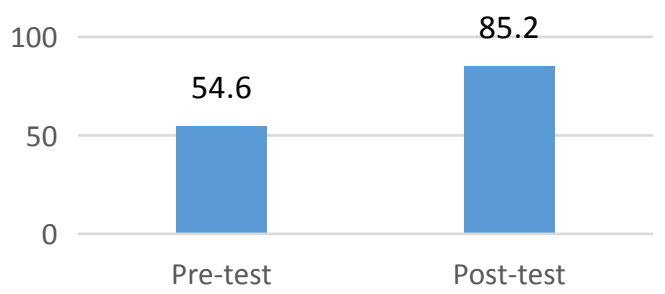

Gambar 8. Grafik perbedaan rata-rata pre-test dan post-test

Selanjutnya peneliti melakukan uji signifikansi perbedaan rata-rata skor pre-test dan post-test dengan menggunakan uji-t. Hasilnya diperoleh thitung sama dengan 17, 28 sedangkan t tabel dengan taraf signifikansi 0,05 adalah 1,72472, karena t hitung lebih besar dari $t$ tabel dapat disimpulkan bahwa terdapat perbedaan yang signifikan sehingga modul cetak 1000 Hari Pertama Kehidupan dikatakan efektif meningkatkan hasil belajar peserta pelatihan.

\section{Pembahasan}

Penelitian ini menghasilkan sebuah produk modul cetak 1000 Hari Pertama Kehidupan bagi Kader Bina Keluarga Balita (BKB). Materi yang disajikan pada produk ini berupa pengetahuan tentang cara menjaga kesehatan, asupan gizi serta cara menstimulasi tumbuh kembang anak pada periode 1000 Hari Pertama Kehidupannya, dimulai 
sejak terjadinya konsepsi (pembentukan embrio dalam kandungan) hingga anak dilahirkan sampai usia 2 tahun. Paket modul cetak 1000 Hari Pertama Kehidupan terdiri dari empat jenis modul, dan satu buku petunjuk penggunaan bagi instruktur/pelatih.

Empat modul terdiri dari : Modul 1 Persiapan Kehamilan, Modul 2 Masa Kehamilan, Modul 3 Masa Persalinan Nifas dan Menyusui, Modul 4 Masa BayiBalita (usia 0-24 Bulan). Setiap modulnya terbagi menjadi beberapa kegiatan belajar. Dalam setiap kegiatan belajar terdapat tujuan pembelajaran, uraian materi, latihan, rangkuman, tes formatif, umpan balik (feed back), daftar pustaka, glosarium, dan pada akhir modul dilengkapi dengan kunci jawaban. Buku petunjuk penggunaan modul merupakan buku panduan bagi para pelatih/widyaiswara dalam pembelajaran menggunakan modul 1000 Hari pertama Kehidupan.

Adapun kelebihan yang dimiliki oleh pengembangan modul cetak 1000 Hari Pertama Kehidupan adalah : (1) isi materi yang ada dalam modul cetak 1000 Hari Pertama Kehidupan menggunakan bahasa yang komunikatif dan mudah dipahami oleh para pembaca khususnya Kader BKB; (2) tampilan desain sampul dan desain isi modul cetak 1000 Hari Pertama Kehidupan ini sangat menarik dan colorful, dan dilengkapi dengan berbagai ilustrasi untuk membantu memperjelas setiap isi materi, sehingga tidak membuat bosan para pembacanya. (3) isi materi yang dibahas dalam modul cetak 1000 Hari Pertama Kehidupan sangat penting dan bermanfaat bukan hanya bagi para peserta pelatihan/ Kader BKB tetapi juga sangat penting bagi para orangtua khususnya ibu-ibu yang akan dan sudah memiliki balita usia 0-2 tahun. (4) modul cetak 1000 Hari Pertama Kehidupan ini dilengkapi dengan petunjuk penggunaan modul bagi peserta pelatihan dan pelatih/widyaiswara sehingga bisa digunakan dalam kelas pelatihan dengan pelatih/ tutor dan juga bisa digunakan secara mandiri oleh kader BKB di rumah.

Adapun Kekurangan yang ada pada modul 1000 Hari Pertama Kehidupan bagi Kader BKB adalah : (1) ruang lingkup materi yang sangat luas, dan terdapat materi yang kurang rinci/detail, sehingga diperlukan referensi lain untuk memperdalam pemahaman para kader. (2) tes sumatif yang dikembangkan tidak diberikan per modul, tetapi dilakukan secara keseluruhan pada akhir pembelajaran. (3) modul yang dikembangkan tidak dilengkapi dengan media pembelajaran yang lain.

Adapun implikasi dari penelitian ini adalah; (1) Memudahkan peserta pelatihan dalam mempelajari materi 1000 Hari Pertama Kehidupan, karena modul ini dapat digunakan kapan saja, dimana saja dan oleh siapa saja; (2) Berdasarkan hasil wawancara dengan widyaiswara, modul yang dikembangkan memberikan dampak yang positif dalam pelaksanaan pelatihan, karena sangat membantu widyaiswara dalam menjelaskan materi tentang 1000 Hari Pertama Kehidupan secara teknis dan lebih detail kepada para peserta pelatihan. (3) Dengan adanya modul 1000 Hari Pertama Kehidupan, peserta pelatihan menjadi lebih semangat dalam mempelajari materi 1000 Hari Pertama Kehidupan. Hal tersebut terlihat dari antusiasme para peserta pelatihan ketika belajar tentang materi $1000 \mathrm{HPK}$ dan hasil post-test yang mengalami peningkatan yang signifikan setelah modul diberikan; (4) Modul yang dikembangkan juga dapat memberikan dampak yang baik dalam pelaksanaan program 1000 Hari Pertama Kehidupan dan pencegahan stunting di Indonesia. Indikatornya para kader menjadi lebih siap dalam memberikan penyuluhan kepada masyarakat tentang pentingnya 1000 Hari Pertama Kehidupan, dan pengetahuan masyarakat pun menjadi lebih baik, sehingga stunting pun dapat dicegah.

\section{PENUTUP}

\section{Kesimpulan}

Pengembangan Modul 1000 Hari Pertama Kehidupan untuk Pelatihan Kader Bina Keluarga Balita (BKB) di BKKBN dilakukan dengan menggunakan tahapan model pengembangan Rowntree. Dimulai dari tahap perencanaan, tahap pengembangan dan tahap evaluasi. Berdasarkan hasil evaluasi terhadap modul, maka diperoleh kesimpulan bahwa modul cetak 1000 Hari Pertama Kehidupan bagi Kader Bina Keluarga Balita (BKB) sudah sangat baik sehingga layak digunakan.
Selain itu hasil uji $\mathrm{t}$ yang dilakukan terhadap modul cetak 1000 Hari Pertama Kehidupan, diperoleh $t$ hitung lebih besar dari $t$ tabel. Hal tersebut dapat disimpulkan bahwa terdapat perbedaan yang signifikan sehingga modul cetak 1000 Hari Pertama Kehidupan dikatakan efektif meningkatkan hasil belajar peserta pelatihan.

Implikasi dari penelitian ini; (1) Memudahkan peserta pelatihan dalam mempelajari materi 1000 Hari Pertama Kehidupan; (2) Modul 1000 Hari Pertama Kehidupan terbukti efektif dalam meningkatkan hasil 
belajar peserta pelatihan, sehingga modul ini layak dan efektif dijadikan sebagai bahan belajar; (3) dengan adanya modul 1000 Hari Pertama Kehidupan, peserta pelatihan menjadi lebih semangat dalam mempelajari materi 1000 Hari Pertama Kehidupan, karena modul dikemas dengan desain yang menarik dan penyajian bahasa yang mudah dimengerti / komunikatif; (4) Berdasarkan hasil wawancara dengan widyaiswara modul yang dikembangkan ini memberikan dampak yang positif bagi pelaksanaan Diklat Teknis menjadi Orangtua Hebat sehingga membantu widyaiswara dalam menjelaskan materi tentang 1000 Hari Pertama Kehidupan kepada para peserta pelatihan. Hal ini dapat terlihat dari antusiasme peserta pelatihan ketika belajar di kelas dan hasil post test yang mengalami peningkatan signifikan setelah modul dibagikan dan dipelajari; (5) Modul yang dikembangkan juga dapat memberikan dampak yang baik, terutama dalam hal peningkatan pengetahuan para kader tentang 1000 Hari Pertama Kehidupan, sehingga akan berdampak positif dalam pelaksanaan program 1000 Hari Pertama Kehidupan dan pencegahan stunting di Indonesia.

\section{Saran}

Adapun rekomendasi/saran sebagai berikut: (1) Perlu dikembangkan sumber belajar berupa modul dalam setiap mata diklat, sehingga dapat mempermudah proses pembelajaran dalam pelatihan; (2) Modul ini dapat dijadikan sebagai sumber belajar mandiri tidak hanya bagi para Kader BKB di seluruh Indonesia, dan juga para ibu-ibu yang akan dan sudah memiliki anak balita; (3) Modul ini dapat dijadikan sebagai salah satu media KIE (Komunikasi, Informasi dan Edukasi) di masyarakat untuk mengatasi tingginya angka stunting di Indonesia

\section{DAFTAR PUSTAKA}

Dewi, BK, 2017, Mengenal "Stunting" dan efeknya pada pertumbuhan anak, Kompas, di akses tanggal 2 November $2017 \mathrm{di}$ : http://health. kompas.com/read/2017/02/08/100300123/ mengenal.stunting.dan.efeknya.pada.pertumbuhan.anak

F, Martin, OJ, Hoskins, R, Brooks dan T, Bannet, 2013, Development of an interactive Multimedia Instructional Module. The Journal of Applied Instructional Design. ISSN: 2160-5289, Vol.3 (3). https://www.rsearchgate.net/publication/272151941

Handoko, Akbar, Sajidan, dan Maridi 2016, Pengembangan Modul Biologi Berbasis Discovery Learning (Part Of Inquiry Spectrum Learning-Wenning) pada materi Bioteknologi Kelas XII IPA di SMA Negeri 1 Magelang Tahun Ajaran 2014/2015, Jurnal Inkuiri: ISSN: 2252-7893, Vol. 5, No.3, http://jurnal.fkip.uns.ac.id/index. php/sains

Heinich, Robert, Michael, M dan James, D, R. 1990. Instructional Media and The New Technologies of Instruction, Third Edition, New York: MacMillan Publishing Company.

Ibrahim, Nurdin. 2010. Perpektif Pendidikan Terbuka Jarak Jauh. Jakarta: PT. Bumi Aksara.

Kementerian Kesehatan. 2015. Buku Saku dan Laporan Lengkap PSG 2015. Jakarta: Kementerian Kesehatan RI.

Oktarina, Zilda dan Trini Sudiarti, 2013, Faktor Risiko Stunting pada Balita (24-59 bulan) di Sumatera,
Bogor: Jurnal Gizi dan Pangan (IPB), November 2013. Vol. 8 No.3, ISSN : 1978-1059.

Pannen, Paulina dan Purwanto. 2001. Penulisan Bahan Ajar. Jakarta: PAU-PPAI. Universitas Terbuka.

Prawiradilaga, Dewi Salma. 2009. Prinsip Disain Pembelajaran. Jakarta: Prenada Media Group.

Rosyidah, Himmah, 2014, Pengembangan Modul Kesehatan Reproduksi Remaja pada Siswa Kelas X SMAN 1 Menganti. Surabaya: Jurnal BK UNESA Vol. 4, No.3.

Rowntree, D. 1994. Preparing Materials for Open, Distance and Flexible Learning, An action Guide for Teachers and Trainers. London: Kogan Page.

Sanders, Nathan E, Chris Faesi dan Alyssa A. G, 2014,. A New Approach to Developing Interactive Software Modules Through Graduate Education, J Sci Educ Technol, 2014 DOI. 10.1007/ s10956-013-9474-4, New York: Springer Science+Bussines Media. https://link.springer.com/ article/10.1007/s10956-013-9474-4

Suparman, M. Atwi. 2014. Desain Instruksional Modern :Panduan para pengajar dan inovator pendidikan. Jakarta: Erlangga.

Sugiyono. 2016. Metode Penelitian Kuantitatif, Kualitatif, dan R \& D. Bandung: Alfabeta.

Torlesse, Harriet. Aidan Anthony Cronin, Susy KS, dan Robin N, 2016, Determinants of stunting in Indonesian children: evidence from a cross-sectional survey indicate a prominent role for the water, sanitation and hygiene sector in stunting reduc- 
Pengembangan Modul Cetak...

tion. BMC Public Health, 16:669, DOI 10.1186 s/d 12889-016-3339-8. SpringerLink. https:// www.ncbi.nlm.nih.gov/pubmed/27472935
Yaumi, Muhammad, Editor: Nurdin Ibrahim dan Darlan Sidik. 2013. Prinsip-Prinsip Desain Pembelajaran. Jakarta: Kencana Prenada Media Group. 